\title{
Special Announcement - Guidelines to the Practice of Anesthesia - Revised Edition 2021
}

\author{
Gregory R. Dobson, MD
}

Received: 20 September 2020/ Accepted: 20 September 2020/Published online: 11 November 2020

(C) Canadian Anesthesiologists' Society 2020

This issue of the Journal features the 2021 revised edition of the Guidelines to the Practice of Anesthesia. ${ }^{1}$ These Guidelines were originally developed, and now updated annually, by the Canadian Anesthesiologists' Society (CAS) Committee on Standards and are approved by the CAS Board of Directors. These Guidelines represent the $44^{\text {th }}$ annual revision since they were first issued in 1977 and the $12^{\text {th }}$ year that they have appeared in the Journal itself. They are intended to provide a broad framework for safe anesthesia practice in Canada, wherever it is delivered. They are frequently cited and well read-the Journal's online version of the 2020 edition has already been downloaded 1,430 times.

This year's release of the updated Guidelines comes at a particularly challenging time as the entire world deals with the ongoing and ever-changing health crisis associated with the coronavirus disease (COVID-19) pandemic. It certainly has been particularly stressful for anesthesiologists as front-line, high-risk healthcare providers. It has required timely and decisive action including the development of protocols and strategies to keep us, our support staff, and our patients safe. While there are no new sections in the Guidelines specific to COVID-19-related patient care or occupational health and safety, the Journal has fast-tracked the editorial and publication processes for a series of

This editorial is related to the 2021 revised edition of the CAS guidelines.

G. R. Dobson, MD ( $ه)$

Committee on Standards, Canadian Anesthesiologists' Society, 1

Eglinton Avenue East, Suite 208, Toronto, ON M4P 3A1,

Canada

e-mails: gdobson@dal.ca; standards@cas.ca related articles resulting, to date, in a 69-article COVID-19 collection. ${ }^{2,3}$

This unprecedented time has certainly been more challenging for the CAS' Committee on Standards and the CAS Board to meet, discuss, and collaborate on the development of changes related to the Guidelines. Despite these obstacles, we are pleased to offer important new content additions to the 2021 revised edition. I wish to sincerely thank all of the members of CAS Standards Committee, the CAS Executive, and CAS Board, as well as the Journal staff, for their tremendous support and flexibility under difficult circumstances. It has permitted the Standards committee to operate as close to business as usual as we could. It would not have been possible to continue our work updating the Guidelines for 2021 without their valuable assistance.

I also wish to applaud all Canadian anesthesiologists, resident trainees, anesthesia assistants (AAs), and technicians for the dedication and commitment that they have shown to their patients, despite the potential for exposure to considerable personal risk and the resulting stresses. Additionally, this has all come at a time of significant anesthesia human resource challenges within Canada, particularly in rural and underserviced areas. We are facing difficult and uncertain times, yet we should all be very proud of each other and remember that we need to continue to work together, be supportive of each other, be kind and collaborative, and try to speak as a unified voice. The CAS accepts the challenge of doing its part to promote these values and will be at the table with a strong voice to support the health and future of our specialty. There is no better time than now to be an engaged member of the Society. I also recommend that members consider availing themselves, as needed, of the resources made available through the new CAS Physician Wellness Committee, 
accessible via the CAS website, ${ }^{\mathrm{A}}$ or other available health and wellness programs. In cooperation with the Wellness Committee, we plan to add more content to the Guidelines in the near future related to the important topic of physician health. ${ }^{4}$

Every year in this editorial, I remind Journal readers that clinical practice guidelines contain recommendations that are synthesized from systematic review and appraisal of available literature. ${ }^{5}$ These recommendations sometimes require an element of expert opinion and committee consensus where quality evidence may be lacking. Suggestions for approaches to the organization and delivery of care should not be viewed as rigid, fixed "standards", unless indicated in the recommendation, such as when the word "must" is used. Individual physicians should still feel confident that their knowledge, experience, and clinical discretion are all as essential and important to the delivery of appropriate anesthesia care as written guidelines are.

The Committee on Standards welcomes questions, comments, and constructive criticism related to the Guidelines. All submitted queries and their related responses are available on the CAS website. ${ }^{\mathrm{B}}$ The commentary in this editorial should be considered as an invitation to any anesthesiologist, allied health professional, or healthcare administrator to report their questions or comments to the Committee on Standards (standards@cas.ca) related to existing content or topics that readers feel would be well suited to being addressed in the Guidelines.

The current and projected anesthesia human resource crisis in Canada has generated considerable concern and has indeed caught the attention of provincial health ministries, health authorities, provincial medical colleges, the Royal College of Physicians and Surgeons (RCPSC), the College of Family Physicians of Canada, and the Association of Canadian Departments of Anesthesia. All of us practicing and training in anesthesiology are deeply concerned about it. A variety of solutions have been put forward such as increasing the number of residency training positions, lobbying the RCPSC and provincial medical colleges to modify requirements for foreign trained anesthesiologists, expanding the scope of practice of AAs, increasing the numbers and utilization of family practice anesthesiologists (FPAs), and considering nurse anesthesia models. No one proposed solution has met with

\footnotetext{
A Canadian Anesthesiologists' Society. Physician Wellness. Available from URL: https://www.cas.ca/en/about-cas/committees/ physician-wellness\# (accessed September 2020).

B Canadian Anesthesiologists' Society. Queries received by the Standards Committee. Available from URL: https://www.cas.ca/ CASAssets/Documents/Practice-Resources/97_Standards-Queriesdocument-June-2015.pdf (accessed September 2020).
}

universal support or consensus. Indeed, there is considerable debate and divide that has been created within our specialty. In reality, the solution may lie in a hybrid of more than one of these options, or with others not yet considered. With respect to FPAs, we know that approximately 500 are now practicing in a variety of settings in Canada and that they provide much needed anesthesia services, in particular to smaller and often more remote underserviced areas. The Guidelines acknowledge this. In their recent letter to the Journal, Kamble, Orser, and Wilson argued that the Guidelines are inaccurate when they state that the clinical case volume of a particular health facility should be what determines the appropriateness of an FPA providing anesthesia care. ${ }^{6}$

The Guidelines state that:

"In communities with the clinical volume to support fulltime anesthesiologists, fellowship-certified anesthesiologists should provide these services".

The Guidelines also state that:

"The Canadian Anesthesiologists' Society (CAS) acknowledges the fact that remote communities often lack the population base to support a specialist anesthesiologist practice. In these communities, appropriately trained family physicians [FPAs] may be required to provide anesthesia services".

Therefore, the Guidelines do recognize the utilization of FPAs in those communities.

The CAS' Standards Committee does agree that, because of the crisis we now face, the "clinical volume" statement arguably oversimplifies the complexity of the situation for both fellowship-trained and FPA providers. It was never intended to be a negative commentary on the value of FPAs. The CAS acknowledges that many communities, even larger ones, cannot recruit and retain fellowship-trained anesthesiologists. The CAS does not have a specific "position" on the role that FPAs may play in the future of anesthesia services in Canada or the current human resource crisis. Nevertheless, the CAS is actively engaged in human resource discussions and forums and wants to be at the table with all authorities and stakeholders to find sustainable solutions to the crisis.

In light of the comprehensive and lengthy nature of the Guidelines document, the remainder of this editorial serves to draw the reader's attention to some of the specific topics updated in this new Guidelines edition, and any available evidence to support these changes. It will also mention several other important topics that were considered but not quite ready for the 2021 edition, but that the Standards Committee plans to continue to develop. The Standards Committee collaborates with the CAS section heads and the CAS Patient Safety Committee when considering areas 
that would benefit from improvement or updating within the Guidelines.

Appendices to the Guidelines, position papers, and other guideline documents are regularly reviewed by the committee and updated as required. To coincide with the release of the 2021 revised edition, and in cooperation with the CAS Committee on the Anesthesia Care Team (COACT), Appendix 5: Position Paper on Anesthesia Assistants $^{7}$ has been extensively revised. A remarkable multidisciplinary effort was required to create the National Competency Framework in Anesthesia Assistance (2016) document. ${ }^{8}$ It now serves as a standardized, validated guide for AA training and practice within Canada. I highly recommend that all anesthesiologists read it. ${ }^{8}$ In response to some important changes to international standards (ISO/ CSA) related to the medical devices and equipment used in the delivery of anesthesia care, we have also released an updated Appendix 1: Canadian Standards Association Standards for Equipment. ${ }^{9}$ Both these documents are available as Appendices in the Electronic Supplementary Material.

The committee actively considered a variety of topics for revision and implemented a number of changes that are highlighted in bold in the revised edition of the Guidelines. The following changes are among those implemented, and they appear in italics below:

1) The 2020 revised edition ${ }^{10}$ had expanded on earlier initiatives to specifically address the safe handling of controlled substances by adding some best practice recommendations under Section 3.1 Responsibilities of the Healthcare Facility. For 2021, new, more general medication safety recommendations have been added in an effort to reduce the potential for medication errors and to acknowledge the impact of the frequent and unpredictable drug shortages and substitutions that we are experiencing ${ }^{11}$ :

"4. There is compliance with all safety regulations and best practice with respect to the storage, preparation, identification, labelling, disposal, and use of medical gases, medications, and related materials.

a. General medication safety recommendations include, but need not be restricted to:

- identifying an anesthesia department lead designated to cooperate with pharmacy to promote medication safety best practice. In recognition of the increased risk of medication errors related to medication brand substitutions and look-alike packaging, departments and pharmacies should consider strategies to reduce this risk.

- requesting that pharmacy notify anesthesia, with as much notice as possible, of upcoming medication supplier, packaging, or concentration changes such that anesthesia staff can be alerted.

- standardization of drug trays across all locations and during product transitions; medications with different supplier brands and packaging for a medication should not be mixed in the same anesthesia cart.

- medication substitutions, particularly of a different concentration, should be labelled with highly visible warning labels during any new medication introduction.

- look-alike medications should be physically separated in the anesthesia carts as much as is possible and identified with warning labels.

- cautioning physicians and technical support staff that replacement of unopened medications back into anesthesia carts is a vulnerable time due to the risk of an incorrect location.

- reporting any medication-related adverse events through local adverse event reporting systems or CAIRS or both."

2) In recent years, the Guidelines have supported the rational and cautious use of preoperative testing, e.g., as promoted by Choosing Wisely Canada. ${ }^{\mathrm{C}}$ Extensive revisions to the test table section of the Guidelines have been made in previous editions. For 2021, we have chosen to add brain natriuretic peptide (BNP), or N-terminal proBNP (NT-pro-BNP), to the test table. Rationalization of preoperative testing has resulted in a significant reduction in preoperative cardiac risk stratification testing in general. Historically in the Guidelines, we have been cautious about using other national or international guidelines as a reference for changes, but in this case, we feel an exception is appropriate. The Canadian Cardiovascular Society Guideline recommendations for screening and surveillance of cardiac disease are evidence-based and validated, and so we have now included their BNP/NT-pro BNP recommendations. ${ }^{12}$ The test table section now includes:

"Brain Natriuretic Peptide (BNP or NT-pro BNP)

May be considered if:

- age $\geq 65 y r$,

- age 45-65 yr with significant cardiac disease,

- Revised Cardiac Risk Index score $\geq 1$."

3) The 2020 revised edition contained some changes to section 4.2 Fasting Guidelines that read:

"An oral $\mathrm{H} 2$ receptor antagonist is recommended the night before and on the morning of an elective Cesarean delivery. An intravenous $\mathrm{H} 2$ receptor antagonist and $30 \mathrm{ml}$

\footnotetext{
C Choosing Wisely Canada. Available from URL: https://choosingwiselycanada.org (accessed September 2020).
} 
of oral 0.3 M sodium citrate are recommended prior to an emergent Cesarean delivery if general anesthesia is planned."

Practice with respect to $\mathrm{H} 2$ antagonists in obstetrical anesthesia differs between facilities, and upon further literature review, we were not able to find evidence to support our specific 2020 recommendations. Therefore, the 2021 revised edition has been changed to read:

"A H2 receptor antagonist (oral or intravenous) is recommended for all women presenting for Cesarean delivery. Thirty $m L$ of sodium citrate $(0.3 \mathrm{M})$ is recommended prior to an emergent Cesarean delivery under general anesthesia."

4) Careful patient positioning during surgery and vigilant rechecking of proper positioning is essential for patient safety. Positioning-related complications can be devastating for the patient, and safe positioning can represent a considerable challenge for the anesthesia and operating room team. ${ }^{13}$ Peripheral nerve injuries are among the most common positioning-related complications. We know that risk varies and that procedural-related factors, patient co-morbidities, and the systemic inflammatory response can all play a role. ${ }^{14}$ Positioning-related injuries cannot always be prevented, despite best practice and vigilance. Nevertheless, the Standards Committee felt strongly that it was time to include some important initial recommendations in the Guidelines. They are first steps and the committee plans to expand on them with more specific best practice recommendations in future editions. They appear as an entirely new section:

"5.7 Patient Positioning

Patient positioning for procedures requiring anesthesia is an operating room team responsibility and demands a high level of attention to avoid complications. It is recognized, however, that positioning-related complications can still occur despite best practice and vigilance. Risks related to patient positioning will vary and depend on the type and duration of surgery, the specific position utilized, and patient factors such as BMI and other comorbidities. Therefore, the considerations and planning for positioning best practice should be discussed by the surgical team ideally before anesthesia induction, for example during Part 1 of the Surgical Safety Checklist. All members of the team, including the anesthesiologist, should be encouraged to voice concerns related to any aspect of positioning (e.g., specific risk factors, availability, condition and appropriateness of OR tables and other positioning equipment) and strategies to mitigate these risks should be considered. Patient positioning should be documented and also rechecked regularly by the anesthesiologist to be sure positioning conditions remain ideal. Patients should be informed preoperatively of any specific risks that may be associated with the position planned for their procedure."

5) It is well known that there can be a risk of barotrauma in patients with cuffed endotracheal tubes when they are receiving ventilation or supplemental oxygen if the egress of gas flow is obstructed. One example is the malfunctioning of the valve on a manual, self-inflating resuscitation bag, or the misuse of the device. ${ }^{15}$ There is also the potential for risk associated with utilizing devices such as oxygen tubing, nasal prongs, face masks, or other devices that are not intended for that application to deliver supplemental oxygen to intubated patients. A recent publicized case in Canada involved bilateral pneumothorax and cardiac arrest in a pediatric dental patient intubated in a recovery room when high flow oxygen was delivered to an endotracheal tube with a nonapproved device. ${ }^{\mathrm{D}}$ Although the case is not yet reported in the anesthesia literature it does reinforce the importance of exercising care when delivering high flow oxygen to an endotracheal tube. Previous editions of the Guidelines have recommended that, if clinically indicated, supplemental oxygen should be applied during patient transfer and in the postanesthesia care unit (PACU). The 2021 editions adds that:

"When supplemental oxygen is applied during transport or in the PACU to patients who are intubated, it is recommended that it only be provided using devices approved for that specific application to minimize any risk of barotrauma complications"

6) The delivery of anesthesia care in remote (i.e., nonoperating room) locations carries both unique challenges for anesthesiologists and potential risks for the patients. The American Society of Anesthesiologists closed-claims database reveals that patient injuries in these remote locations often involve older, more complex patients. These injuries are also generally of a higher severity, reflect a higher occurrence of substandard care, and are deemed more preventable than claims originating from traditional operating rooms. ${ }^{16}$ Procedural sedation accounts for over $50 \%$ of the claims. There has been tremendous growth in the volume and complexity of procedures and therefore the demand for anesthesia services in remote locations, both within and outside of hospital settings (including private clinics). Non-operating room anesthesia deserves special attention because of a variety of unique circumstances and considerations. ${ }^{17}$ The Standards Committee has extensively updated the Guidelines in acknowledgement of this fact, and provides

\footnotetext{
D $C B C$. 'Absolute hell': parents say daughter, 5, almost died after routine dental surgery. Available from URL: https://www.cbc.ca/ news/canada/saskatchewan/dental-surgery-child-near-death1.5312048 (accessed September 2020).
} 
recommendations and support to anesthesiology leadership through the promotion of the safest possible facilities. One of the most important recommendations is that anesthesiologists should have appropriately trained support personnel (e.g., AA) readily available to assist them. Facilities that do not have AAs should utilize other appropriately trained personnel, but the hope is that these recommendations will encourage facilities that do not have AAs to consider having them become part of the anesthesia care team. Section 9 Guidelines for Practice of Anesthesia Outside a Hospital Facility has been replaced as follows:

"9.0 Guidelines for the Practice of Anesthesia in Remote Locations

The basic principles, training requirements, techniques, equipment, and medications used for the practice of anesthesia in remote locations are as outlined in other sections of these Guidelines. They apply equally to anesthesia care, including procedural sedation (see Appendix 6), delivered by anesthesiologists in any operating room or out-of-operating room locations both within a hospital facility and in locations outside of a hospital facility (e.g., offices, clinics).

9.1 Anesthesia Care delivered in a Non-Hospital Medical/Surgical/Dental Facility

\subsubsection{Patient Selection}

The physical status of patients should be classified using the American Society of Anesthesiologists physical status (ASA) score. Typically, only patients with ASA classifications of I and II should be considered for procedures. Patients with ASA III classification may be accepted under certain circumstances but only at the discretion of the attending anesthesiologist. Caution should be exercised when booking patients with a known difficult airway.

\subsubsection{Preoperative Considerations}

The patient must have had a recent and documented health history, physical examination including an airway examination, and any appropriate laboratory investigations. This may be carried out by another physician (e.g., proceduralist) but it is strongly recommended that there be a screening process that is developed and supported by the anesthesia leadership providing services. The duration of fasting should be consistent with section 4.2 Fasting Guidelines.

\subsubsection{Conduct of Anesthesia}

The anesthetic and recovery facilities must conform to facility standards established by the CSA (see Appendix 1) and all CAS guidelines established for patient care. The patient should be discharged home from the facility using a validated scoring system for fitness to discharge (e.g., Post Anesthetic Discharge Scoring System [PADSS]). Patients should be provided with written instructions for the preoperative and postoperative periods.
9.2 Anesthesia Care delivered Outside of an Operating Room within a Hospital or in a Non-Hospital Facility

The demand for the delivery of anesthesia care services outside of an operating room (e.g., endoscopy, interventional radiology, cardiac catheterization) is growing because of technological advances and increased availability of less invasive, yet potentially painful, procedures. The delivery of anesthesia care in these remote procedural units can present unique challenges to the anesthesia care team (e.g., patients may be ASA III-IV and have significant comorbidities) and they may be some distance from the operating rooms and support staff or outside of a hospital facility. Procedural units where anesthesiologists have been asked to provide care should comply with the same CSA standards (Appendix 1), equipment guidelines (see section 3.0), and general CAS guidelines as an operating room to the greatest extent possible. This includes, but need not be restricted to, patient selection and assessment, preprocedural testing, fasting guidelines, equipment and electrical outlets, oxygen and suction, ventilation and scavenging if inhalational agents will be utilized, medications and equipment required for resuscitation, patient monitoring, the recovery facility, and anesthesia support personnel. Any location outside of an operating room where anesthesiologists provide care must be approved by the anesthesia leadership of the facility. Appropriately trained and experienced anesthesia support personnel, e.g., an Anesthesia Assistant (see section 2.5) or other staff with experience supporting anesthesia should be present or immediately available to assist the anesthesiologist in remote locations. It is not appropriate to rely solely on procedural unit staff to support anesthesia unless they have had training and experience in the direct support of the delivery of anesthesia care and are approved by anesthesia leadership. There must be reliable two-way communication available to call for assistance and support the anesthesia provider as it may be required."

Other topics that the Standards Committee are actively discussing for future guideline editions include additional content for Section 5.2 Airway Management, environmental sustainability in anesthesia, physician health and wellness (including leave and retirement guidelines), anesthesia human resources in Canada, and an update to the sections related to obstetrical anesthesia.

In closing, on behalf of the CAS' Standards Committee, I wish to express gratitude to those readers who have provided us with comments and suggestions. Readers are encouraged to continue with their submissions. These submitted suggestions help to focus the committee efforts and to support the over-arching goal to create Guidelines that are as specific as possible, yet practical and widely applicable. Furthermore, one of our most important 
mandates is to provide anesthesiologists and their leadership the support and evidence that they require to lobby their institutions and health authorities for the resources that they need. In doing so, the highest levels of patient safety and professionalism can be continuously optimized.

\section{Communiqué spécial - Guide d'exercice de l'anesthésie - Édition révisée 2021}

Ce numéro du Journal présente l'édition révisée du Guide d'exercice de l'anesthésie 2021. ${ }^{1}$ Originellement mis au point et aujourd'hui mis à jour annuellement par le Comité des normes de la Société canadienne des anesthésiologistes (SCA), ce Guide est approuvé par le Conseil d'administration de la SCA. Il s'agit de la $44^{\mathrm{e}}$ révision annuelle du Guide depuis sa première édition en 1977 , et de sa $12^{\mathrm{e}}$ publication dans le Journal. L'objectif de ce Guide est de procurer un cadre général pour une pratique sécuritaire de l'anesthésie au Canada et ce, peu importe où elle est pratiquée. Il est fréquemment cité et abondamment lu - pour preuve les 1430 téléchargements à ce jour de la version électronique du Journal de l'édition 2020.

Cette année, la publication du Guide survient à un moment particulièrement difficile, alors que le monde entier est aux prises avec la crise de santé en constante évolution provoquée par la pandémie de COVID-19. Cette année a indubitablement été singulièrement stressante pour les anesthésiologistes en tant que fournisseurs de soins de santé de première ligne à haut risque. Cette crise a nécessité des actions rapides, notamment par la mise au point de protocoles et de stratégies afin de garantir notre sécurité, celle de notre personnel de soutien, et celle de nos patients. Alors que le Guide ne contient pas de nouvelle section abordant spécifiquement les soins aux patients liés à la COVID-19 ou à la santé et à la sécurité au travail, le Journal a néanmoins accéléré les processus éditoriaux et de publication d'une série d'articles sur le sujet générant, à ce jour, une collection de 69 articles portant sur la COVID$19 .^{2,3}$

En raison de ces temps sans précédent, il a été bien plus difficile pour le Comité des normes de la SCA et pour le Conseil d'administration de la SCA de se rencontrer, de discuter et de collaborer afin de mettre au point les modifications pertinentes au Guide. Malgré ces obstacles, nous avons le plaisir de présenter d'importants nouveaux ajouts au contenu de l'édition révisée 2021. Je tiens à remercier du fond du cœur tous les membres du Comité des normes de la SCA, du Comité directeur de la SCA, du Conseil d'administration ainsi que du personnel du Journal pour leur soutien et leur flexibilité sans bornes dans ces conditions éprouvantes. Grâce à eux, le Comité des normes a pu fonctionner quasi normalement. Il n'aurait pas été possible de poursuivre notre travail de mise à jour du Guide 2021 sans leur soutien précieux.

Je tiens également à tirer mon chapeau à tous les anesthésiologistes, résidents, assistants en anesthésie (AA) et techniciens canadiens pour le dévouement et l'engagement dont ils ont fait preuve envers leurs patients et ce, malgré l'important risque d'exposition potentielle qu'ils couraient personnellement, sans compter le stress concomitant. En outre, tout cela est arrivé à un moment où les défis en matière de ressources humaines en anesthésie sont majeurs - particulièrement dans les régions rurales ou mal desservies. Nous sommes confrontés à des temps difficiles et incertains, et pourtant nous pouvons tous être fiers les uns des autres et nous souvenir que nous devons continuer de travailler ensemble, nous épauler mutuellement, faire preuve d'amabilité et de collaboration, et de tenter de parler d'une seule et même voix. La SCA accepte le défi de faire sa part pour promouvoir ces valeurs et sera là pour parler d'une voix forte afin de soutenir la santé et l'avenir de notre spécialité. C'est le moment parfait pour s'engager comme membre de la Société. J'invite également les membres à profiter, au besoin, des ressources mises à leur disposition via le nouveau Comité pour le bien-être des médecins de la SCA; ces ressources sont accessibles sur le site Internet de la $\mathrm{SCA}$, ${ }^{\mathrm{A}}$ et d'autres programmes de santé et de bien-être sont également disponibles ailleurs. En coopération avec le Comité pour le bien-être, nous planifions, dans un avenir proche, ajouter au Guide du contenu lié au thème crucial de la santé des médecins. 4

Chaque année dans cet éditorial, je rappelle aux lecteurs du Journal que les Guides de pratique clinique comportent des recommandations qui font la synthèse de la revue systématique et de l'évaluation de la littérature disponible. Lorsque les données probantes de qualité ne suffisent pas, les lignes directrices se fondent parfois sur une part d'opinion d'experts et de consensus du comité. Les approches proposées pour l'organisation et la fourniture des soins ne devraient pas être interprétées comme des « normes » rigides et figées, à moins que la ligne directrice ne l'indique clairement, par l'utilisation du verbe « devoir » et de ses conjugaisons, par exemple. Chaque médecin doit continuer de se fier à ses connaissances, à son

\footnotetext{
A Société canadienne des anesthésiologistes. Le comité pour le bienêtre des médecins. Disponible à l'adresse URL : https://www.cas.ca/ fr/a-propos-de-la-sca/comites/le-comite-pour-le-bien-etre-desmedecins\# (consulté Septembre 2020).
} 
expérience, ainsi qu'à sa discrétion clinique : tous ces éléments sont tout aussi essentiels et importants pour la fourniture de soins anesthésiques adaptés que les lignes directrices écrites.

Le Comité des normes accueille volontiers toute question, tout commentaire, et toute critique constructive en ce qui concerne le Guide. Toutes les questions soumises et les réponses associées sont disponibles sur le site Internet de la SCA. ${ }^{\mathrm{B}}$ Le commentaire dans cet éditorial doit être lu comme une invitation à tout anesthésiologiste, professionnel paramédical ou administrateur de soins de santé, à adresser ses questions ou commentaires au Comité des normes (standards@cas.ca) en ce qui a trait au contenu du Guide existant ou à des thèmes qui mériteraient d'y être abordés.

La crise actuelle et projetée en matière de ressources humaines en anesthésie au Canada a suscité d'importantes inquiétudes et attiré l'attention des ministères de santé provinciaux, des autorités de santé, des collèges médicaux provinciaux, du Collège royal des médecins et chirurgiens du Canada (CRMCC), du Collège des médecins de famille du Canada et de l'Association des départements d'anesthésiologie des universités canadiennes (ACUDA). Nous tous qui pratiquons ou qui formons pour pratiquer en anesthésiologie sommes très inquiets de cette pénurie. Diverses solutions ont été proposées, comme par exemple d'augmenter le nombre de postes de formation en résidence, de faire pression auprès du CRMCC et des collèges médicaux provinciaux afin qu'ils modifient leurs exigences pour les anesthésiologistes formés à l'étranger, d'élargir le champ de pratique des AA, d'augmenter le nombre et l'utilisation des anesthésiologistes en médecine familiale (AMF) et d'envisager des modèles d'infirmiers et infirmières en anesthésie. Aucune des solutions proposées n'a obtenu un soutien ou un consensus universel. En effet, le débat et la division créés au sein de notre spécialité sont importants. En vérité, la solution se trouve peut-être dans une mouture hybride associant plus d'une de ces options, ou dans d'autres possibilités non encore envisagées. En ce qui a trait aux AMF, nous savons qu'ils sont environ 500 à pratiquer dans diverses conditions au Canada et qu'ils fournissent des services d'anesthésie plus que nécessaires, en particulier dans des régions plus petites et souvent mal desservies et isolées. Le Guide reconnaît cette pratique. Dans leur récente lettre au Journal, Kamble, Orser et Wilson avancent que le Guide est inexact lorsqu'il indique que le volume de cas cliniques d'un établissement de santé

\footnotetext{
B Société canadienne des anesthésiologistes. Requêtes reçues par le comité des normes de pratique. Disponible à l'adresse URL : https://www.cas.ca/CASAssets/Documents/Practice-Resources/ 97_Standards-Queries-document-June-2015.pdf (consulté Septembre 2020).
}

devrait être le facteur qui détermine si les soins anesthésiques devraient être dispensés par un AMF. ${ }^{6}$

Selon le Guide :

"Dans les communautés où le volume clinique est suffisamment important pour justifier l'emploi d'anesthésiologistes à temps plein, des anesthésiologistes ayant complété leur spécialisation devraient offrir ces services. »

Toujours selon le Guide :

«La Société canadienne des anesthésiologistes (SCA) reconnaît que la population dans les collectivités éloignées n'est souvent pas suffisamment nombreuse pour justifier une pratique d'anesthésiologie spécialisée. Dans ces collectivités, des médecins de famille ayant reçu une formation adéquate [AMF] pourraient être appelés à dispenser les services d'anesthésie. "

Par conséquent, le Guide reconnaît effectivement le recours aux AMF dans ces collectivités.

Le Comité des normes de la SCA convient que, en raison de la crise à laquelle nous sommes confrontés, l'énoncé concernant le «volume clinique » simplifie probablement trop la complexité de la situation, tant pour les anesthésiologistes certifiés que pour les AMF. L'intention n'a jamais été de commenter péjorativement la valeur des AMF. La SCA est consciente que de nombreuses collectivités, dont certaines de taille considérable, ne parviennent pas à recruter et garder des anesthésiologistes ayant complété leur spécialisation. La SCA ne prend pas de "position » spéciale quant au rôle que les AMP pourraient jouer dans les services anesthésiques au Canada à l'avenir ou durant la crise en matière de ressources humaines que nous traversons actuellement. Toutefois, la SCA est très impliquée dans des discussions et des forums portant sur les ressources humaines et veut s'asseoir avec toutes les autorités et parties prenantes afin de trouver des solutions durables à cette crise.

Étant donné la nature exhaustive et la longueur du Guide, le reste de cet éditorial a pour but d'attirer l'attention du lecteur sur certaines mises à jour spécifiques dans la nouvelle version du Guide et à toutes les données probantes disponibles justifiant ces modifications. Il y sera également fait mention de plusieurs autres thèmes importants qui ont été envisagés mais n'étaient pas tout à fait prêts pour l'édition 2021, mais que le Comité des normes a l'intention de continuer à mettre au point. Le Comité des normes collabore avec les chefs de section de la SCA et le Comité de la sécurité des patients de la SCA lorsqu'il réfléchit aux domaines qui pourraient bénéficier d'améliorations ou de mises à jour dans le Guide.

Les annexes du Guide, énoncés de position et autres documents de recommandations sont régulièrement révisés 
par le Comité et mis à jour au besoin. Afin de coïncider avec la publication de l'édition révisée de 2021, et en coopération avec le Comité sur les équipes de soin en anesthésie (CESA) de la SCA, l'Annexe 5: Exposé de principe sur les assistants en anesthésie ${ }^{7}$ a fait l'objet d'une révision approfondie. Un effort multidisciplinaire remarquable a été nécessaire afin de créer le 'Référentiel national des compétences pour l'assistance en anesthésie' (National Competency Framework in Anesthesia Assistance (2016) - document existant en anglais seulement à ce jour). ${ }^{8} \mathrm{Ce}$ document sert aujourd'hui de guide validé et standardisé pour la formation et la pratique des $\mathrm{AA}$ au Canada. Je recommande fortement à tous les anesthésiologistes de le lire. $^{8}$ En réponse à diverses modifications importantes des normes internationales (ISO/CSA) liées aux dispositifs et équipements médicaux utilisés pour la fourniture de soins anesthésiques, nous avons également publié une version mise à jour de l'Annexe 1: Association canadienne de normalisation Normes concernant le matériel. ${ }^{9}$ Ces deux documents sont disponibles sous forme d'annexes dans le Matériel électronique supplémentaire.

Le Comité a examiné en détail plusieurs sujets pour les réviser et a apporté de nombreuses modifications, lesquelles sont surlignées en gras dans la version révisée du Guide. Ci-dessous vous trouverez en italique certaines des modifications apportées :

1) L'édition révisée $2020^{10}$ avait approfondi les initiatives précédentes abordant spécifiquement la manipulation sécuritaire des substances réglementées en ajoutant certaines recommandations de meilleures pratiques sous la Section 3.1 Responsabilités de l'établissement de santé. En 2021, des lignes directrices plus générales concernant la sécurité des médicaments ont été ajoutées dans le but de réduire les erreurs médicamenteuses potentielles et de tenir compte de l'impact des pénuries et substitutions fréquentes et imprévisibles de médicaments auxquelles nous sommes confrontées ${ }^{11}$ :

«4. L'entreposage, la préparation, l'identification, l'étiquetage, l'elimination et l'utilisation des gaz médicaux, des médicaments et du matériel afférent doivent être conformes à toutes les règles de sécurité.

b. Les recommandations concernant la sécurité des médicaments comprennent, sans nécessairement s'y limiter :

- L'identification d'une personne-ressource désignée au sein du département d'anesthésie qui coopère avec la pharmacie afin de promouvoir les meilleures pratiques en matière de sécurité des médicaments. Afin de tenir compte du risque accru d'erreurs médicamenteuses liées aux substitutions des médicaments de marque et aux emballages similaires, les départements et les pharmacies devraient elaborer des stratégies pour réduire ces risques.

- La demande que la pharmacie informe le personnel d'anesthésie, dans les meilleurs délais possibles, de tout changement de fournisseur médical, d'emballages ou de concentrations afin que le personnel d'anesthésie soit vigilant.

- La standardisation des plateaux de médicaments dans tous les emplacements et pendant les transitions de produit; les médicaments provenant de différents fabricants et dont les emballages diffèrent ne devraient pas être melangés sur un même chariot d'anesthésie.

- Lors de toute introduction de nouveau médicament, les substitutions de médicaments, particulièrement à des concentrations différentes, devraient être étiquetées à l'aide d'étiquettes de mise en garde particulièrement visibles.

- Les médicaments ayant une ressemblance visuelle devraient être, autant que possible, séparés dans les chariots d'anesthésie et identifiés à l'aide d'étiquettes de mise en garde.

- Les médecins et le personnel de soutien technique doivent être mis en garde que la remise de médicaments non ouverts dans le chariot d'anesthésie est risquée parce que les médicaments pourraient être disposés au mauvais emplacement.

- Tout événement indésirable lié à un médicament doit être rapporté via les systèmes locaux de surveillance des événements indésirables ou via le CAIRS (système de déclaration des incidents en anesthésie), ou les deux. »

2) Dans les dernières années, le Guide a appuyé l'utilisation rationnelle et prudente des examens préopératoires, comme par exemple les examens recommandés par l'initiative Choisir avec soin Canada. ${ }^{\mathrm{C}}$ Des révisions majeures à la section des tableaux d'examens du Guide ont été apportées dans les éditions précédentes. En 2021, nous avons décidé d'ajouter le peptide cérébral natriurétique (BNP), ou N-terminal pro-BNP (NT-proBNP), au tableau des examens. Les efforts de rationalisation des examens préopératoires ont généralement entraîné une réduction significative des examens préopératoires de stratification du risque cardiaque. Lors de nos révisions précédentes du Guide, nous avons toujours fait preuve de prudence dans l'utilisation de lignes directrices nationales ou

\footnotetext{
C Choisir avec soin. Disponible à l'adresse URL : https:// choisiravecsoin.org/ (consulté Septembre 2020).
} 
internationales différentes en tant que référence pour l'apport de modifications. Dans ce cas particulier toutefois, nous pensons qu'il faut faire une exception. Les recommandations du Guide de la Société canadienne de cardiologie pour le dépistage et la surveillance des cardiopathies sont fondées sur des données probantes et validées, c'est pourquoi nous avons inclus leurs recommandations concernant le BNP/NT-pro BNP. ${ }^{12} \mathrm{La}$ section du tableau des examens inclut désormais :

$$
\begin{aligned}
& \text { «Le peptide cérébral natriurétique (BNP ou NT-pro } \\
& B N P \text { ) }
\end{aligned}
$$$$
\text { peut être envisagé si : }
$$

- le patient est âgé $\geq 65$ ans,

- le patient est âgé de 45-65 ans et a une condition cardiaque significative,

- le patient a un score à l'Index cardiaque de risque révisé $\geq 1$. »

3) L'édition révisée de 2020 comprenait des modifications à la section 4.2 Lignes directrices concernant le jeûne, selon lesquelles :

"Un antagoniste oral des récepteurs $H 2$ de l'histamine est recommandé la nuit précédant et le matin d'un accouchement par césarienne programmé. Un antagoniste intraveineux des récepteurs $\mathrm{H} 2$ de l'histamine et $30 \mathrm{~mL}$ de citrate de sodium molaire 0,3 oral sont recommandés avant un accouchement par césarienne urgent si l'on planifie une anesthésie générale. »

La pratique en ce qui touche les antagonistes des récepteurs $\mathrm{H} 2$ en anesthésie obstétricale varie beaucoup d'un établissement à l'autre et, après une revue approfondie de la littérature, nous n'avons pu trouver de données probantes appuyant nos directives spécifiques de 2020. Par conséquent, l'édition révisée de 2021 a été modifiée comme suit :

«Un antagoniste des récepteurs H2 (oral ou intraveineux) est recommandé pour toutes les femmes devant subir un accouchement par césarienne. Trente (30) $m L$ de citrate de sodium (0,3 molaire) sont recommandés avant un accouchement par césarienne urgent si l'on planifie une anesthésie générale. »

4) Pour garantir la sécurité des patients, il est essentiel de procéder à leur positionnement méticuleux pendant la chirurgie et de vérifier scrupuleusement que le positionnement soit adéquat. Les complications liées au positionnement peuvent être dévastatrices pour un patient, et un positionnement sécuritaire peut constituer un véritable défi pour l'équipe d'anesthésie et de la salle d'opération. ${ }^{13}$ Les lésions nerveuses périphériques comptent parmi les complications liées au positionnement les plus répandues. Nous savons que le risque varie et que les facteurs liés à l'intervention, les comorbidités des patients et la réaction inflammatoire systémique peuvent tous jouer un rôle. ${ }^{14}$ Les lésions liées au positionnement ne peuvent pas toujours être évitées et ce, même en dépit des meilleures pratiques et de notre vigilance. Toutefois, le Comité des normes a déterminé qu'il était temps d'inclure d'importantes recommandations initiales à cet égard dans le Guide. Il s'agit de premiers pas et le Comité a l'intention d'approfondir le sujet avec des lignes directrices des meilleures pratiques plus spécifiques dans les prochaines éditions. Ces recommandations forment une toute nouvelle section :

\section{«5.7 Positionnement du patient}

Le positionnement du patient pour les interventions nécessitant une anesthésie est une responsabilité de l'ensemble de l'équipe de la salle d'opération et requiert un niveau très élevé d'attention afin d'éviter toute complication. Il est entendu, cependant, que les complications liées au positionnement peuvent tout de même survenir malgré l'application des meilleures pratiques et d'une haute vigilance. Les risques associés au positionnement du patient varieront et dépendront $d u$ type et de la durée de la chirurgie, de la position spécifique utilisée, et de facteurs liés au patient tels que l'IMC et d'autres comorbidités. Par conséquent, les considérations et la planification du positionnement selon les meilleures pratiques devraient faire l'objet de discussions au sein de l'équipe chirurgicale. Dans l'idéal, ces discussions doivent avoir lieu avant l'induction de l'anesthésie, par exemple au cours de la première partie de la Liste de contrôle de la sécurité chirurgicale. Tous les membres de l'équipe, y compris l'anesthésiologiste, devraient être encouragés à exprimer leurs préoccupations concernant tout aspect $d u$ positionnement quel qu'il soit (par ex., facteurs de risque spécifiques et disponibilité, état et choix adapté des tables de SOP ou d'autre matériel de positionnement), et des stratégies visant à mitiger ces risques devraient être mises en cuvre. Le positionnement du patient doit être documenté et vérifié régulièrement par l'anesthésiologiste afin de s'assurer que les conditions du positionnement demeurent idéales. Les patients devraient être informés avant l'opération de tout risque spécifique possiblement associé au positionnement prévu pour leur intervention. "

5) Le risque de barotraumatisme est bien connu chez les patients intubés avec des sondes endotrachéales avec ballonnet lorsqu'ils reçoivent une ventilation ou de l'oxygène supplémentaire et que la sortie des gaz est obstruée. Par exemple, la valve de l'insufflateur manuel de réanimation autogonflant pourrait ne pas bien fonctionner, ou le dispositif pourrait être mal utilisé. ${ }^{15}$ Il existe également des risques associés à l'utilisation de dispositifs tels que les tubulures d'oxygène, les pinces nasales, les masques faciaux ou autres dispositifs non conçus pour administrer de l'oxygène supplémentaire aux 
patients intubés. Au Canada, un cas a récemment été publicisé, impliquant un pneumothorax bilatéral et un arrêt cardiaque chez un patient de dentisterie pédiatrique intubé, en salle de réveil : de l'oxygène à haut débit a été administré via le tube endotrachéal avec un dispositif non approuvé. ${ }^{\mathrm{D}}$ Bien que ce cas clinique ne soit pas encore rapporté dans la littérature anesthésique, il souligne l'importance de faire preuve de prudence lors de l'administration d'oxygène à haut débit dans un tube endotrachéal. Les éditions précédentes du Guide recommandaient que, lorsque cela était indiqué d'un point de vue clinique, de l'oxygène supplémentaire devrait être administré pendant le transfert des patients et en salle de réveil. L'édition 2021 complète cette ligne directrice comme suit :

"Si de l'oxygène supplémentaire est administré à des patients intubés pendant le transport ou en salle de réveil, afin de minimiser tout risque de barotraumatisme, il est fortement recommandé de ne le fournir qu'avec des dispositifs approuvés pour cette application spécifique. »

6) La prestation de soins anesthésiques dans les lieux isolés (c.-à-d. hors de la salle d'opération) comporte de nombreux défis pour les anesthésiologistes tout en ajoutant des risques potentiels pour les patients. La base de données des réclamations réglées de l'American Society of Anesthesiologists révèle que les lésions aux patients dans ces lieux isolés surviennent souvent chez des patients plus âgés et plus 'complexes'. En règle générale, ces lésions sont également plus graves, reflètent une incidence plus élevée de soins en-deçà des normes, et sont jugés plus évitables que les réclamations liées à des événements survenus dans des salles d'opération traditionnelles. ${ }^{16} \mathrm{La}$ sédation consciente est impliquée dans plus de $50 \%$ des réclamations. Nous avons assisté à une très forte augmentation du volume et de la complexité des interventions et par conséquent de la demande pour des services anesthésiques dans les lieux isolés, tant dans un cadre hospitalier qu'en dehors des institutions (y compris dans les cliniques privées). L'anesthésie hors de la salle d'opération mérite une attention spéciale en raison de diverses circonstances et considérations uniques. ${ }^{17} \mathrm{Le}$ Comité des normes a mis à jour en détail le Guide pour tenir compte de cette réalité et offre des lignes directrices et du soutien aux responsables de l'anesthésiologie en faisant la promotion d'installations les plus sécuritaires possibles. L'une des recommandations les plus importantes est que les anesthésiologistes devraient avoir du personnel de soutien adéquatement formé (par ex. des AA) à leur

\footnotetext{
D $C B C$. 'Absolute hell': parents say daughter, 5, almost died after routine dental surgery. Disponible à l'adresse URL: https://www. cbc.ca/news/canada/saskatchewan/dental-surgery-child-near-death-1. 5312048 (consulté Septembre 2020).
}

disposition immédiate pour les assister. Les établissements qui ne disposent pas d'AA devraient employer d'autres personnes adéquatement formées, mais nous espérons que les présentes lignes directrices encourageront les établissements qui n'ont pas de AA à envisager de les intégrer à leur équipe de soins anesthésiques. La Section 9: Lignes directrices pour l'exercice de l'anesthésie hors du milieu hospitalier a été remplacée par ce qui suit :

«9.0 Lignes directrices pour l'exercice de l'anesthésie dans les lieux isolés

Les principes fondamentaux, les exigences de formation, les techniques, le matériel et les médicaments utilisés pour la pratique de l'anesthésie dans les lieux éloignés ont été documentés dans d'autres sections de ce Guide. Ils s'appliquent également aux soins anesthésiques, notamment à la sédation consciente (voir Annexe 6) dispensée par un anesthésiologiste dans toute salle d'opération ou emplacement hors de la salle d'opération, tant à l'intérieur d'un établissement hospitalier qu'à l'extérieur (par ex. bureaux, cliniques).

9.1 Soins anesthésiques dispensés dans un établissement médical/chirurgical/dentaire non hospitalier

9.1.1 Selection des patients

Le statut physique des patients devrait être catégorisé selon le score de l'American Society of Anesthesiologists (ASA). D'une manière générale, seuls les patients des classes ASA I et II devraient être retenus pour subir une intervention. Les patients de statut ASA III pourraient être acceptés sous certaines conditions, mais seulement à la discrétion de l'anesthésiologiste en charge. Il faut faire preuve de prudence lors de la sélection de patients présentant des voies aériennes difficiles connues.

\subsubsection{Considérations préopératoires}

Une histoire de cas et un examen physique récents, incluant un examen des voies aériennes, devraient paraittre au dossier du patient, ainsi que les résultats des examens de laboratoire appropriés. Ces examens peuvent être exécutés par un autre médecin (par ex. un 'procéduraliste', soit un médecin/chirurgien compétent pour réaliser des interventions diagnostiques ou thérapeutiques), mais l'existence d'un processus de selection mis au point et endossé par la direction des services anesthésiques est fortement recommandée. La durée du jê̂ne devrait être conforme à la section 4.2 Lignes directrices concernant le jeûne.

\subsubsection{Conduite de l'anesthésie}

Les installations des salles d'anesthésie et de réveil doivent être conformes aux normes hospitalières établies par la CSA (voir Annexe 1) et à toutes les lignes directrices de la SCA établies pour les soins aux patients. Le patient devrait recevoir son congé de l'hôpital pour rentrer à la maison en utilisant un système de notation validé évaluant 
son aptitude au congé (par. ex. Système de cotation de congé post-anesthésique [PADSS]). Les patients devraient recevoir des instructions écrites concernant les périodes préopératoire et postopératoire.

9.2 Soins anesthésiques dispensés hors de la salle d'opération dans un hôpital ou un établissement non hospitalier

En raison des avancées technologiques et de la plus grande disponibilité d'interventions moins invasives mais potentiellement douloureuses, la demande pour la fourniture de soins anesthésiques à l'extérieur de la salle d'opération (par ex., endoscopie, radiologie interventionnelle, cathétérisation cardiaque) crott. La fourniture de soins anesthésiques dans ces unités interventionnelles eloignées peut s'accompagner de défis particuliers pour l'équipe de soins anesthésiques ( $p$. ex., les patients pourraient avoir un statut ASA III-IV et d'importantes comorbidités), et ces unités pourraient se trouver à une certaine distance des salles d'opération et du personnel de soutien, voire à l'extérieur d'un établissement hospitalier. Les unités d'intervention dans lesquelles les anesthésiologistes sont appelés à fournir des soins devraient se conformer, dans la mesure du possible, aux mêmes normes de la CSA (Annexe 1), lignes directrices concernant le matériel d'anesthésie (voir section 3.0), et lignes directrices générales de la SCA qu'une salle d'opération. Cela comprend, sans s'y limiter, la sélection et l'évaluation des patients, les examens pré-procéduraux, les lignes directrices concernant le jeûne, le matériel et les prises électriques, l'oxygène et la succion, la ventilation et l'évacuation des agents volatils si utilisés, les médicaments et le matériel nécessaires à la réanimation, le monitorage $d u$ patient, les installations de rétablissement et le personnel de soutien en anesthésie. Tout lieu où des anesthésiologistes fournissent des soins en dehors d'une salle d'opération doit être approuvé par la direction de l'anesthésie dans l'établissement. Du personnel de soutien en anesthésie adéquatement formé et expérimenté, par exemple un assistant en anesthésie (voir section 2.5) ou d'autres personnes ayant de l'expérience dans le soutien en anesthésie, devrait être présent ou immédiatement disponible pour assister l'anesthésiologiste dans les lieux isolés. Il ne convient pas de dépendre exclusivement du personnel de l'unité chirurgicale pour soutenir l'anesthésie, à moins que ce personnel ne soit formé et ait de l'expérience dans le soutien direct de la fourniture de soins anesthésiques et qu'il ait reçu l'aval de la direction de l'anesthésie. Une communication bidirectionnelle fiable doit être disponible pour que le prestataire d'anesthésie ait accès à de l'aide et du soutien si nécessaire."

Parmi les autres sujets que le Comité des normes évalue actuellement pour les éditions futures du Guide, citons l'ajout de contenu à la Section 5.2 Prise en charge des voies aériennes, la viabilité environnementale en anesthésie, la santé et le bien-être des médecins (y compris des lignes directrices concernant les congés et la retraite), les ressources humaines en anesthésie au Canada, et une mise à jour des sections portant sur l'anesthésie obstétricale.

En conclusion, au nom du Comité des normes de la SCA, j'aimerais remercier les lecteurs qui nous ont fait parvenir des commentaires et des suggestions. Nous vous encourageons à continuer de nous écrire. Les propositions soumises nous aident à concentrer les efforts du Comité et soutiennent l'objectif central de créer un Guide aussi spécifique que possible tout en restant pratique et facile d'application. En outre, l'un de nos mandats principaux est de fournir aux anesthésiologistes et aux entités qui en sont responsables le soutien et les données probantes nécessaires pour faire pression sur leurs établissements et leurs autorités sanitaires afin d'obtenir les ressources dont ils ont besoin. Ce faisant, les plus hauts niveaux de sécurité des patients et de professionnalisme peuvent continuer d'être optimisés.

Acknowledgements I thank the Journal editorial staff, specifically Ms. Carolyn Gillis and Dr. Hilary Grocott, for their patient and tireless attention in assisting with the Guidelines and the accompanying editorials throughout my time as chair of the CAS' Standards Committee.

Disclosures None.

Funding statement None.

Editorial responsibility This submission was handled by Dr. Hilary P. Grocott, Editor-in-Chief, Canadian Journal of Anesthesia.

Remerciements Je tiens à remercier le bureau de rédaction du Journal, particulièrement Mme Carolyn Gillis et Dr Hilary Grocott, pour leur attention patiente et infatigable ainsi que leur aide pour la mise à jour du Guide et des éditoriaux associés tout au long de mon mandat à la tête du Comité des normes de la SCA.

Déclaration Aucune.

Déclaration de financement Aucune.

Responsabilité éditoriale Cet article a été traité par Dr Hilary P. Grocott, rédacteur en chef, Journal canadien d'anesthésie.

\section{References}

1. Dobson G, Chow L, Filteau L, et al. Guidelines to the Practice of Anesthesia - Revised Edition 2021. Can J Anesth 2021. DOI:https://doi.org/10.1007/s12630-020-01842-x

2. Asenjo JF. Safer intubation and extubation of patients with COVID-19. Can J Anesth 2020; 67: 1276-8. 
3. Lockhart SL, Duggan LV, Wax RS, Saad S, Grocott HP. Personal protective equipment (PPE) for both anesthesiologists and other airway managers: principles and practice during the COVID-19 pandemic. Can J Anesth 2020; 67: 1005-15.

4. Alikhani R, Salimi A, Hormati A, Aminnejad R. Mental health advice for frontline healthcare providers caring for patients with COVID-19. Can J Anesth 2020; 67: 1068-9.

5. Kredo T, Bernhardsson S, Machingaidze S, et al. Guide to clinical practice guidelines: the current state of play. Int J Qual Health Care 2016; 28: 122-8.

6. Kamble V, Orser BA, Wilson CR. Developing practice guidelines for anesthesia services in rural Canada: the importance of the family physician perspective. Can J Anesth 2020. DOI:https://doi. org/10.1007/S12630-020-01728-y.

7. Dobson, $G$, Chow L, Filteau L, et al. Guidelines to the Practice of Anesthesia - Revised Edition 2021. Appendix 5 - Position Paper on Anesthesia Assistants: An Official Position Paper of the Canadian Anesthesiologists' Society. Available as Electronic Supplementary Material. Can J Anesth 2021. DOI:https://doi.org/ 10.1007/s12630-020-01842-x

8. Canadian Society of Respiratory Therapists. National Competency Framework in Anesthesia Assistance (2016). Available from URL: www.csrt.com/wp-content/uploads/ Validated2016AANationalCompetencyFramework.pdf (accessed September 2020).

9. Dobson, G, Chow L, Filteau L, et al. Guidelines to the Practice of Anesthesia - Revised Edition 2021. Appendix 1 - Canadian Standards Association - Standards for Medical Devices and Equipment. Available as Electronic Supplementary Material. Can J Anesth 2021. DOI:https://doi.org/10.1007/s12630-020-01842-x
10. Dobson G, Chow L, Filteau L, et.al. Guidelines to the practice of anesthesia - revised edition 2020. Can J Anesth 2020; 67: 64-99,

11. Wahr JA, Abernathy JH 3rd, Lazarra EH, et al. Medication safety in the operating room: literature and expert-based recommendations. Br J Anaesth 2017; 118: 32-43.

12. Duceppe E, Parlow J, MacDonald $P$, et al. Canadian Cardiovascular Society Guidelines on Perioperative Cardiac Risk Assessment and Management for Patients Who Undergo Noncardiac Surgery. Can J Cardiol 2017; 33: 17-32.

13. MacDonald JJ, Washington SJ. Positioning the surgical patient. Anaesth Intensive Care Med 2012; 13: P528-32.

14. Johnson RL, Warner ME, Staff NP, Warner MA. Neuropathies after surgery: anatomical considerations of pathological mechanisms. Clin Anat 2015; 28: 678-82.

15. Cooper RM, Grgas $S$. Fatal barotrauma resulting from misuse of a resuscitation bag. Anesthesiology 2000; 93: 892-3.

16. Metzner J, Posner KL, Domino KB. The risk and safety of anesthesia at remote locations: the US closed claims analysis. Curr Opin Anesthesiol 2009; 22: 502-8.

17. Walls JD, Weiss MS. Safety in non-operating room anesthesia (NORA). Anesthesia Patient Safety Foundation Newsletter 2019. Available from URL: https://www.apsf.org/article/safetyin-non-operating-room-anesthesia-nora/ (accessed September 2020).

Publisher's Note Springer Nature remains neutral with regard to jurisdictional claims in published maps and institutional affiliations. 